\title{
High Order Thinking Skills Instrument on Microeconomics Course: A Development Research
}

\begin{tabular}{lllll}
\multicolumn{2}{l}{ Retno Mustika Dewi } \\
$\begin{array}{l}\text { Faculty of Economic, } \\
\text { retnomustika@unesa.ac.id }\end{array}$ & Universitas & Negeri & Surabaya, & Indonesia, \\
$\begin{array}{l}\text { Ni'matush Sholikhah } \\
\begin{array}{l}\text { Faculty of Economic, } \\
\text { nimatushsholikhah@unesa.ac.id }\end{array}\end{array}$ & Universitas & Negeri & Surabaya, & Indonesia, \\
$\begin{array}{l}\text { Dhiah Fitrayati } \\
\begin{array}{l}\text { Faculty of Economic, } \\
\text { dhiahfitrayati@unesa.ac.id }\end{array}\end{array}$ & Universitas & Negeri & Surabaya, & Indonesia,
\end{tabular}

Microeconomics course is a course relating to individual problems in meeting needs. So that require students' evaluation sheets which has high-level thinking ability standards that correlate with real life problems. The objectives of this study are (1) describing the feasibility of developing questions about Demand and Supply on the Economic Education student, (2) describing the high-level thinking skills of Economic Education students. This research is a development research type formative research. The product of this activity is assessment instruments for Introduction to Microeconomic Theory course. The results showed that the development of test instruments to measure students' higher order thinking skills categorized as very feasible. The students' higher order thinking skills categorized as good category.

Keywords: development of test instruments, high order thinking skills, microeconomics, thinking skills, microeconomics

\section{INTRODUCTION}

Alfred Marshall defined Economics as a science that teaches ways of thinking and making decisions in order to meet needs. During this time the problem is the limitation resources in order to meet diverse human needs while human desire is unlimited. So that not all human desires are fulfilled. Facing this reality, humans must be rational by making choices on the diversity of human needs. In order to obtain convenience in 
making choices, priority scale development is needed (Mankiw, 2008; Nicholson, 2002).

One branch of Economics is Microeconomics. Microeconomics is the science that explains in general behavior of economic system and discuss economic actors within the economic system. In addition, Microeconomics also studies how individuals use their own resources in optimum level of satisfaction. Explanation of the basic concepts of microeconomic theory includes economic problems, economic activities, economic actors, demand and supply, price mechanisms, elasticity, determination policies prices by the government, and market structure. The concepts will help in solving problems to achieve solutions with existing variables and combine them in the stages of decision making (Mankiw, 2008; Nicholson, 2002).

According to Economics theory, demand and supply are two things that are related and very important. Demand and supply represent the relationships between seller and buyer in a market, namely the interaction of a seller and buyer of a product, both goods and services. Demand itself has the meaning as a number of products whether goods or services are purchased or demanded by consumers at a certain price and time. Whereas supply is a number of products whether goods or services are sold or offered by producers in a certain time and place.

This supply and demand model can be used to determine the price and quantity of products sold in the market. This model is an important aspect in conducting microeconomic analysis, especially on the behavior between buyers and sellers and the interactions that occur between them. In addition, this model can also be used as a turning point for various other economic models and theories. This model also predicted that in a competitive market price serves as a balance between the quantity of demand from consumers and supply conducted by the manufacturer. This model also allows for a change in a balance caused by several factors, then the data is displayed through a shift in demand and supply curves (Mankiw, 2008; Nicholson, 2002).

In maintaining its survival, humans need various kinds of goods or services as a means of satisfying needs. Needs are something that is always inherent in human beings. In connection with this, the demand and supply are concepts that are close to everyday life. Because humans are always do transactions in order to meet their needs. It is undeniable that in the economic life of producers and consumers is a unit that is very difficult to separate, the life of producers is very dependent on the level of demand from consumers, and this makes consumers compete to get offers as high as the high, this market system that continues continuously until now. Many people assume that economics begins and ends with the law of demand and supply (Mankiw, 2008; Nicholson, 2002).

Therefore we need to understand what is meant by supply and demand itself, and the first thing is we need to know what influences the determination of prices, demand and supply of certain commodities, how demand and supply determine prices and how the price system as a whole allows the economic system to react to changes in demand and changes in supply. 
The variation of methods in teaching and learning activities raise variations in the assessment of student learning outcomes. Sudirman (2012) states that student learning outcomes are indicators to find out (1) student learning progress, both as individuals and group members or classes after he has attended education and learning in a predetermined period of time, (2) knowing various levels of effectiveness and efficiency the learning component used by the teacher for a certain period of time. The learning component for example concerns the formulation of learning materials, the selection of learning methods, media, learning resources, and the design of the assessment system chosen, (3) determine the follow-up of learning for students, and (4) help students to choose schools, jobs, and positions that are in accordance with their talents, interests, concerns, and abilities.

Microecomics courses correlate with the problem of meeting human needs. Thus, it requires evaluation tools related to real human problems. In this regard, a measurement tool is needed to describe the achievements of students' understanding of the material that has been studied. The learning outcome measurement tools should provide learning experiences include cognitive, affective, and psychomotor abilities. So that the learning experience can be used to solve the problems of daily life, especially problems related to demand and supply.

Based on the level of process, thinking is divided into two levels, namely lower order thinking and higher-order thinking. This thinking ability requires someone to apply new information or prior knowledge and manipulate information to reach possible answers in new situations. Bloom's taxonomy explains that abilities involve analysis, evaluation and creation are considered high order thinking (Pohl, 2000). High order thinking is thinking at a higher level than just memorizing facts or saying information to someone (Heong, Y. M., Othman, W.D., Md Yunos, J., Kiong, T.T., Hassan, R., \& Mohamad, 2011).

According Amalia (2013) states that high order thinking skills are a capacity above the information provided, with a critical attitude to evaluate, have metacognitive awareness and have problem-solving abilities. According to Stein, high order thinking uses complex thinking, non algorithmic for completing a task, some are unpredictable, using different approaches to tasks that already exist and different from examples (Lewy, 2009) . So, high order thinking is the ability to manipulate information and ideas in ways that change meaning and implications, combine facts and ideas in order to synthesize, generalize, explain, interpret and draw conclusions.

The research objectives include: 1) describing the feasibility of developing Test Instruments on Economic Education Student request and supply material; 2) describe the ability of high-level students to think in Economics Education in the subject matter of demand and supply.

\section{METHOD}

This study uses development research methods with formative research type (Tessmer, 1993). 


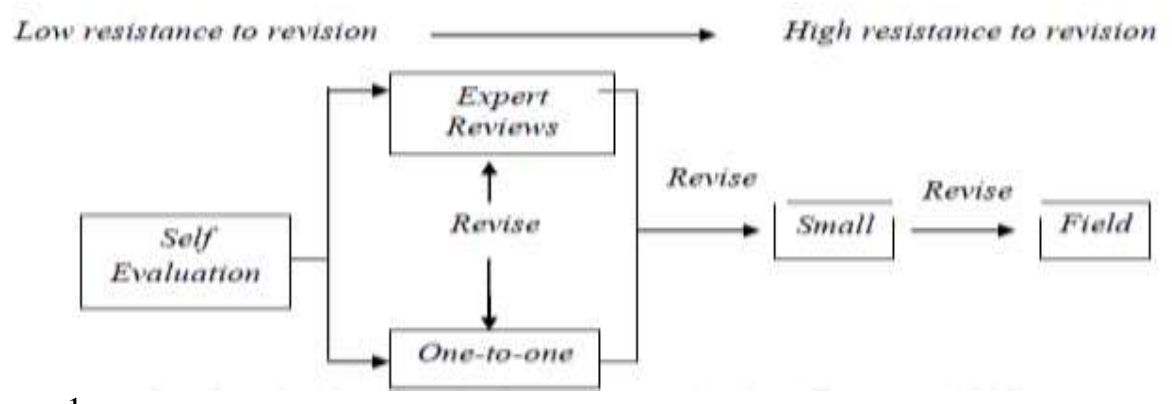

Figure 1

Flow of Formative Evaluation Design (Tessmer, 1993)

Development research as a type of research aimed at producing questions to measure high order thinking skills, through several stages, as follows. The HOTS indicators are use cognitive levels such as C4 (analysis), C5 (synthesis), and C6 (evaluation).

\section{Preliminary Stage}

This stage aimed to determine the place and subject of the research that will be used as the location of the research as well as hold other preparations, such as arranging the schedule of research and procedures for collaboration with class teachers who will be used as research sites.

\section{Self Evaluation Stage}

This stage is the initial step of development research. Researchers will analyze students need, material analysis, curriculum and literature, which are in accordance with the curriculum.

Table 1

Basic Competency Formulation on material Requests and offers

\begin{tabular}{lll}
\hline Meeting & Final ability & Indicator \\
\hline $4-5$ & Analyze & Can explain Law of demand and supply \\
& requests and offers & Can explain the factors that influence demand and supply. \\
& & Can explain demand and supply curves \\
& Can explain the functions of demand and supply \\
& Can calculate the functions of demand and supply
\end{tabular}

Source: (Team, 2018)

\section{Design Phase}

At this stage, the researcher designed questions to measure ability high level thinking on material requests and offers. This product design is a prototype. Each prototype focuses on three characteristics, namely: content, construct, and language. 
Table 2

The Characteristics that Became the Focus of the Prototype

\begin{tabular}{ll}
\hline Content & questions of high level thinking ability is appropriate with: \\
& - Basic competencies \\
& - Indicator \\
\hline Construct & Questions in accordance with the theory support by criteria: \\
& - Develop the ability to analyze, evaluate and create \\
& - Rich with Concepts \\
& - In accordance with the level of students \\
& - there are clear instructions on how to work on the problem \\
& - images, graphics, or the like are presented clearly and legibly \\
\hline Language & - In accordance with EYD (Indonesian correct spelling) \\
& - Problem is not complicated \\
& - The question does not contain multiple interpretations \\
& - Limitation of questions and answers clear \\
- using common language
\end{tabular}

Source: (Lewy, Zulkardi, 2009)

These three characteristics are validated by experts and peers. This method is known as the triangulation technique.

\section{Prototyping (validation, evaluation and revision).}

At this stage the product that was made earlier will be evaluated. In this evaluation phase the product will be tested. There are 3 trial groups: a) Expert Review; b) expert judgment; c) one-to-one

\section{Trials}

\section{Small group}

The results of the expert suggestion and the students' experience on the first prototype were used as the basis for the revision of the first prototype design called the second prototype. Then the results were tested on the small group (5 non-research subjects). At this stage, 5 students will be asked to solve the questions that have been designed. Based on the results of the test results and student comments, the product was revised and improved.

\section{Field test}

Suggestions and results of trials on the second prototype were used as the basis for revising the design of the second prototype. The revised results were tested on the research subject in this case as a field test. This phase of the revised product trial is being tested to students of Economics Education Department who are taking an introductory course in Microeconomics theory. 


\section{FINDINGS}

\section{Preliminary Stage}

This development research was conducted at the Economics Faculty of the State University of Surabaya. The research subjects were students of the 2018 Economics Education Department who took the Introduction to Microeconomic Theory courses.

\section{Self Evaluation}

At this stage will be explained about student analysis, curriculum, and analysis of devices and materials developed. The first is the analysis of students, the average student is in the age range between 18 years and 19 years. Based on Piaget's cognitive development level (Trianto, 2014), the age range is at the stage of development of formal operations. The main characteristic of development at this stage is that children are able to think abstractly and logically with use patterns of thinking "possibilities" and models of scientific thinking with type hypothetical deductive and inductive children have begun to have, with the ability to draw conclusion, interpret and develop hypotheses. Therefore, this ability is in accordance with the needs of this study, namely the ability to solve problems through questions that include high order thinking skills. Furthermore, students have already received material requests and offers during their studies at the secondary education level. Based on experience, they have only worked on questions that require short answers, in the form of memorization/ memories that do not reach high order thinking skills, so that when faced with complex questions and adapted to daily experiences, students experience difficulties.

Furthermore, the second stage is curriculum analysis. The curriculum used by students in the subject of this research is curricula 2018. The material used is demand and supply in the introductory subject of Microeconomics theory. Following is the description of the curriculum.

Table 3

Curriculum Analysis

\begin{tabular}{|c|c|c|}
\hline No. & Basic competencies & Indicator \\
\hline 1 & Analyze request and offer & $\begin{array}{l}\text { Describe the request } \\
\text { Explain the Law of demand } \\
\text { Explain the factors that influence demand } \\
\text { Create a request table } \\
\text { Make a demand curve } \\
\text { Calculate the request function } \\
\text { Describe the offer } \\
\text { Explaining the law of supply } \\
\text { Explain the factors that influence the offer } \\
\text { Make a bidding table } \\
\text { Make a supply curve } \\
\text { Calculate the bid function }\end{array}$ \\
\hline
\end{tabular}

The test developed in this study is a written test in the form of a description question. The question is based on the material contained in the introductory subject of 
microeconomic theory, namely material demand and supply. The test developed consists of 8 sections which cover material requests and offers. Questions that have been prepared include understanding cases, curves, and counting. The following is presented in the design grid of the test development and the test design developed.

Table 4

Grid of Questions

\begin{tabular}{|c|c|c|c|c|c|c|}
\hline Problem Indicator & Cognitive & ain & & & & Number of questions \\
\hline & $\mathrm{C} 1 \quad \mathrm{C} 2$ & $\mathrm{C} 3$ & $\mathrm{C} 4$ & $\mathrm{C} 5$ & C6 & \\
\hline $\begin{array}{l}\text { Analyze the } \\
\text { problem presented }\end{array}$ & & & $\bar{X}$ & & & $\begin{array}{l}\text { Problem parts I }(1,2,5,6,7 \text {, } \\
10) \text { and the questions in } \\
\text { part II (1.1 and } 1.2)\end{array}$ \\
\hline $\begin{array}{l}\text { Evaluate the } \\
\text { problem presented }\end{array}$ & & & & $\mathrm{X}$ & & Problem parts I (4 and 8) \\
\hline $\begin{array}{l}\text { Create images of } \\
\text { the problems } \\
\text { presented }\end{array}$ & & & & & $\mathrm{X}$ & $\begin{array}{l}\text { Problem parts } 1(3,9) \text { and } \\
\text { questions part II }(1.3 \text { and } \\
4.1)\end{array}$ \\
\hline
\end{tabular}

Indicator of Analyze the problems presented including C4 (analysis), indicators of Evaluate the problems presented including C5 (synthesis) and indicator of Create images of the problems presented including C6 (evaluation).

\section{Prototyping}

The test designs that have been compiled are then given to experts for review. Experts referred to in the study include: a) material experts, b) evaluation experts, and c) linguists. For expert evaluation carried out by Riza Yonisa Kurniawan, S.Pd, M.Pd. Draft question design is also given to students to be used as revised material for researchers.

Based on expert evaluation review, obtained suggestions in the form of comments which include (1) less specific problem instructions, (2) assessment rubric is not complete, (3) scoring guidelines do not exist yet, and (4) the tenth $\left(10^{\text {th }}\right)$ need to be reviewed in relation to the context. The following are presented in the review and revision items. 
Table 5

The Results of the Evaluation Expert's Review

\begin{tabular}{lll}
\hline Component & Study & Repair \\
\hline the instructions & Instructions: & Instructions: \\
are less specific & Do this test in sequence & a. Do this test in sequence \\
& Do this test briefly and concise & b. Read the question carefully \\
& & $\begin{array}{l}\text { c. Each question has the equal score } \\
\text { d. Draw demand curve and supply } \\
\text { curve according to the question. }\end{array}$ \\
& & \begin{tabular}{l} 
curve \\
\hline
\end{tabular}
\end{tabular}

\begin{tabular}{ll}
\hline $\begin{array}{l}\text { assessment } \\
\text { rubric is not }\end{array}$ & The assessment rubric has not \\
complete &
\end{tabular}

Assessment Instrument:

1. For question type A

Amount of questions $=10$

Students get 20 point in every

question, as long as they can

answer correctly.

Total score $=100$

2. For question type $B$

Amount of questions $=4$

Students get 25 point in every

question, as long as they can

answer correctly.

Total score $=100$

Final score $=($ total score of question type

Scoring

guidelines do

not yet exist

\section{Assessment Instrument:}

3. For question type A

Amount of questions $=10$

Students get 20 point in every

question, as long as they can

answer correctly.

Total score $=100$

4. For question type B

Amount of questions $=4$

Students get 25 point in every

question, as long as they can

answer correctly.

Total score $=100$

Final score $=($ total score of question type

A + total score of question type B)/2

the question

Explain the solution for this case,

Explain the solution for this case,

number 10 (ten) according to the theory of according to the theory of demand and needs to be demand and supply. Smoking can

reviewed interfere people health and supply. Consume junk food frequently will damage people health. Is it possible surrounding. Is it possible if the amount of cigarette demand if the quantity of junk food demand decreases? 
The results of the evaluation expert's review included the researchers correcting the problem questions, assessment rubrics, scoring guidelines and fixing those question.

Table 6

Evaluation Results of Expert Evaluation

\begin{tabular}{|c|c|c|c|}
\hline Aspect & Assessment Indicator & Score & Percentage \\
\hline \multirow[t]{4}{*}{$\begin{array}{l}\text { Substance / } \\
\text { material }\end{array}$} & $\begin{array}{l}\text { Questions in accordance with the material or study } \\
\text { material }\end{array}$ & 5 & $100 \%$ \\
\hline & $\begin{array}{l}\text { Questions include the application of knowledge in } \\
\text { phenomena in life and technology }\end{array}$ & 4 & $80 \%$ \\
\hline & $\begin{array}{l}\text { Material that is measured in accordance with the } \\
\text { competency or purpose of the test is to measure high } \\
\text { order thinking skills }\end{array}$ & 4 & $80 \%$ \\
\hline & $\begin{array}{l}\text { Questions are in accordance with the level of } \\
\text { development of students who are the subject }\end{array}$ & 4 & $80 \%$ \\
\hline \multirow{4}{*}{$\begin{array}{l}\text { Constructio } \\
\mathrm{n} / \text { question } \\
\text { component }\end{array}$} & $\begin{array}{l}\text { Instructions for working out the question using } \\
\text { command sentences that require answers to break down }\end{array}$ & 4 & $80 \%$ \\
\hline & $\begin{array}{l}\text { Information and commands on questions are easily } \\
\text { understood by students }\end{array}$ & 4 & $80 \%$ \\
\hline & Scoring guidelines exist & 4 & $80 \%$ \\
\hline & $\begin{array}{l}\text { Images, graphs, tables, diagrams and the like are clearly } \\
\text { presented, and function so as not to cause different } \\
\text { interpretations }\end{array}$ & 4 & $80 \%$ \\
\hline \multirow[t]{4}{*}{ Language } & The formulation of communicative questions & 4 & $80 \%$ \\
\hline & $\begin{array}{l}\text { Item questions use language that is in accordance with } \\
\text { Indonesian rules }\end{array}$ & 4 & $80 \%$ \\
\hline & Maximum total score & 50 & $100 \%$ \\
\hline & Total score & 41 & $82 \%$ \\
\hline
\end{tabular}

Based on the table, the development of the instrument is stated with very decent criteria with a score of $82 \%$. The score is obtained from (1) the substance / content component with an average score of $80 \%$ (feasible), (2) the construct component with an average score of $80 \%$ (feasible) and (3) the language component with an average score $(80 \%)$.

\section{Trials}

\section{Small group}

At this stage, a design trial was carried out which had been completed for 3 students (limited trial). The intended students are students of class 2018 A who have taken an introductory course on microeconomic theory.

\section{Field test}

After going through a design trial in the previous stage, the next step is to conduct a field trial that is carried out in the 2018 class Economics Education class that takes the introductory Microeconomics course. Products tested at this stage have passed quality criteria, namely validity, practicality, and effectiveness. This pilot activity begins with the researcher explain the material briefly about supply and demand, while students 
listen the explanation carefully. Next is a question and answer session between researchers (instructors) and students. After there are no questions, the researcher gives a question sheet based on the concept of high order thinking skills for each student to answer and solve. Before students start working, researchers provide explanations and instructions to students regarding the questions that have been shared.

Based on the learning outcomes data, there were 26 students who scored the same or more than the minimum score (75) and 7 other students obtain below- minimum scores (75). The mean data from the value obtained is 77.8. Thus, classical completeness is $78.78 \%$.

\section{DISCUSSION}

\section{The Feasibility of Developing Test Instruments about Higher Level Thinking Capabilities}

The feasibility of developing a test instrument about high thinking skills in the material demand and supply of Economics Education students is seen from the results of expert validation, especially evaluation. In this development research, expert validation was carried out by the evaluation expert, Riza Yonisa Kurniawan, S.Pd, M.Pd, as a lecturer in the Universitas Negeri Surabaya Economics Education Department. The validation results for the feasibility of evaluation in the form of quantitative descriptive data, then the data in the form of numbers are analyzed descriptively.

Based on the results of a review from the evaluation expert, there were several suggestions for improving the development of the question instrument. These suggestions include (1) the instructions less specific questions, (2) the assessment rubric is not complete, (3) the scoring guidelines do not exist yet, and (4) the question number 10 (ten) needs to be reviewed in relation to the context. Moreover, the question instruments that have been prepared have been corrected and revised according to the advice of the evaluation expert. Based on evaluation expert evaluation, the development of test instruments were very feasible with a score of $80 \%$. the eligibility criteria include the content component, construct component, and language component.

The results of the study are in accordance with the research by (Merta Dhewa Kusuma, Undang Rosidin, Abdurrahman, 2017) in his article entitled "The Development of Higher Order Thinking Skill (Hots) Instrument Assessment In Physics Study". Explained in the article, (1) indicator of the ability to analyze (C4) which has been developed are ability to analysis of factual, conceptual, procedural, and metacognitive knowledge; (2) indicator of the ability to evaluate (C5) which has been developed are ability to evaluate of factual, conceptual, procedural, and metacognitive knowledge; (3) Indicator of the ability to create (C6) that has been developed are ability to create of conceptual, procedural, and metacognitive knowledge; (4) the HOTS assessment instrument as assessment for learning is effective to train student's HOTS and effective measure student's thinking skills in accordance with the level of each student's thinking.

Therefore, in this study, it is recommended for students to always improve their literacy, reasoning and high motivation in order to solve every problem given in various 
questions. Furthermore, for teachers to get used to compile contextual questions to practice reading skills which are the basis for developing reasoning abilities.

The ability of high order thinking students of Economic Education In the subject matter of requests and offers

The measurement of students' high order thinking skills is done through field tests (field test) on Economics Education students who have been taken Microeconomics Introductory courses. The trial activity begins with the distribution of the question instruments to each student. the question instrument is in accordance with the indicators of high order thinking ability which includes analyzing activities (C3), evaluating (C4), and creating (C5).

Based on the learning outcomes data obtained data that as many as 26 students who obtained grades equal to or more than minimum score of 75 and 7 other students scored under the minimum score. Thus classical completeness is $78.78 \%$. Based on these scores, the category of high order thinking ability of students is in the good category. Furthermore, based on the evaluation results, data is obtained that students still have difficulties in analyzing (C3) especially for questions related to factors that influence the movement and shift of the curve both the demand curve and the supply curve. So that the difficulty in analyzing a problem also has an impact on creative activities (C4), namely in drawing movements, shifting demand and supply curves. The results of this study are in accordance with (Lewy, 2009) stated that high order thinking uses complex, non-algorithmic thinking to accomplish a task, some which cannot be predicted, uses a different approach to the existing and different tasks from the example. Therefore, it is recommended for students to train themselves to work on questions that are almost the same as the questions that have been developed with different content and for the teacher to use a set of questions that have been developed to train students to get used to working on questions that measure high order thinking skills.

\section{CONCLUSION}

The conclusions of this study are: 1) Development of test instruments to measure students' high order thinking skills in the very feasible category; 2) The ability to think high-level of Economics Education students on material demand and supply is in the good category.

Based on the results of the above research, it can be stated that efforts to improve reasoning abilities, especially in the high order thinking abilities of students are very important, because these abilities are needed to solve problems related to daily life. Therefore, it is important to develop questions that measure high order thinking skills.

\section{REFERENCES}

Amalia, R. (2013). Application of proof learning models to improve high-level mathematical thinking ability in high school students. Jurnal Pendidikan Matematika Universitas Pendidikan Indonesia.

Heong, Y. M., Othman, W. D., Md Yunos, J., Kiong, T. T., Hassan, R., \& Mohamad, 
M. (2011). The level of Marzano higher order thinking skills among technical education students. International Journal of Social and Humanity, 1(2), 121-125.

Lewy, \& Zulkardi, N. A. (2009). Development of questions to measure high order thinking skill for line and number sequence material at $\mathrm{x}$ acceleration class in xaverius maria Junior High School palembang. Journal of Mathematics Education, 3(2), 15-28.

Mankiw, N. G. (2008). Principles of microeconomics. USA: Cengage Learning.

Kusuma, M. D., Rosidin, U., Abdurrahman, A. S., \& Suyatna, A. (2017). The development of higher order thinking skill (Hots) instrument assessment in physics study. IOSR Journal of Research \& Method in Education (IOSR-JRME), 7(1), 26-32.

Nicholson, W. (2002). Intermediate microeconomics and applications. Jakarta: Erlangga.

Pohl, M. (2000). Learning to think, thinking to learn: Models and strategies to develop a classroom culture of thinking. Cheltenham: Hawker Brownlow.

Sudirman. (2012). RPP function. Retrieved from http://makalahpendukasisudirman.co.id/2012/05/fungsi-rpp.html.

Team. (2018). Unesa syllabus document course Introduction to microeconomic theory. Surabaya: Unipress.

Tessmer, M. (1993). Planning and conducting formative evaluations. London: Kogan.

Trianto. (2014). Designing innovative, progressive, and contextual learning models. Jakarta: Prenandamedia Grup. 